\section{A Cyanocobalamin-Protein Complex from Sow's Milk and Desiccated Pig Stomach}

We have already reported the partial purification from sow's milk and desiccated pig stomach of proteins which combine with cyanocobalamin and the vitamin $B_{12}$-like substances having different nucleotide groups ${ }^{1}$. Purification of the protein from sow's milk whey was achieved by continuous electrophoresis on paper2. Because of the labjle nature of the protein itself, we found it easier to saturate the impure concentrate with cyanocobalamin labelled with cobalt-60 and to isolate the cyanocobalaminprotein complex. Purification of this complex by continuous electrophoresis on paper ${ }^{2}$ was followed by repeated fractionation with isopropyl alcohol at - 5०. A recent preliminary note by Wijmenga, Thompson, Stern and O'Connell ${ }^{3}$, concerning a similar cyanocobalamin-protein from pig gastric mucosa, has prompted us to give a brief account of the properties of our substance isolated from sow's milk. Full experimental details will be published elsewhere.

The pink protein complex from sow's milk has the absorption spectrum shown in Fig. 1. The absorption at $278 \mathrm{~m} \mu$ is largely due to protein $(E(1 \%, 1 \mathrm{~cm})=$. $15 \cdot 1)$ and at $362 \mathrm{~m} \mu$ to cyanocobalamin ( $E(1 \%$, $1 \mathrm{~cm}.)=5 \cdot 7)$. The total nitrogen (micro-Kjeldahl) is $16 \cdot 1$ per cent, and $1 \mathrm{mgm}$. of the complex contains $23 \cdot 6 \mu \mathrm{gm}$. cyanocobalamin. From these figures, and assuming that one molecule of protein combines with one molecule of cyanocobalamin (mol. wt. $=1,300$ ), the molecular weight of the protein would be 55,000 . Qualitative examination of the hydrolysed complex shows an amino-acid pattern typical of proteins. Spectroscopic investigations, by the method of Holiday, shows the rather high tyrosine content of 17.6 per cent. The presence of 7 per cent hexosamine suggests a glycoprotein rather than a mucoprotein.

Cyanocobalamin exists in the milk of the sow, woman, rat, goat and cow in bound forms. Gregory, Ford and Kon ${ }^{5}$ showed that sow's mill, but not cow's milk, combined with added cyanocobalamin. However, this procedure involved heating the milks with the assay medium. We have since developed an ultra-filtration method which shows that all these milks when raw and untreated can bind some added cyanocobalamin. Compared with sow's milk, the amount bound by the other milks is small. The electrophoretic mobility of the naturally occurring bound cyanocobalamin in all the milks and of the complexes formed by adding cyanocobalamin to these milks or to desiccated pig stomach was $-3 \cdot 1 \times 10^{-5} \mathrm{~cm} .{ }^{2} \mathrm{~V} .^{-1}$ sec. ${ }^{-1}$ at $p H \mathrm{H} \cdot 6, \mu=0.05$.

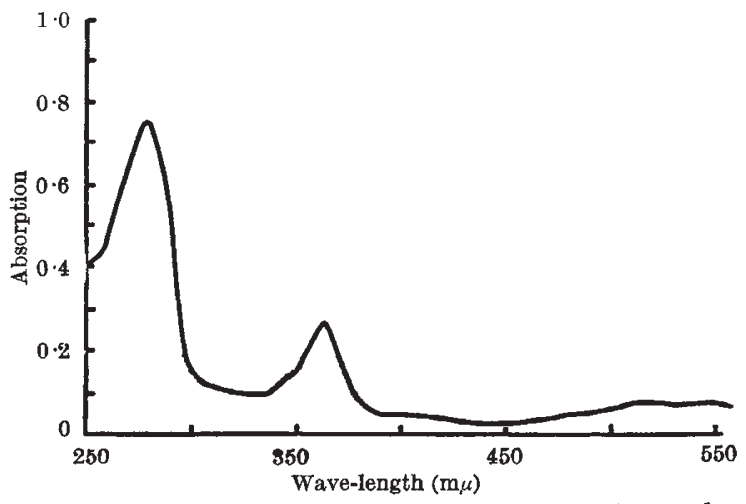

Fig. 1. Absorption curve of cyanocobalamin - protein complex in aqueous solution $(0.5 \mathrm{mgm} . / \mathrm{ml}$.)
We have also investigated the mode of linkage between cyanocobalamin and the protein. Removal of the nucleotide and the most labile amide group from the cyanocobalamin molecule ${ }^{B}$ did not prevent its combination, but hydrolysis to the hexa- or heptaacids $^{8}$ gave a substance which could no longer be combined with the protein. The absorption curve (Fig. 1) with a peak at $362 \mathrm{~m} \mu$ suggests that the complex contains cyano- rather than hydroxocobalamin. When ${ }^{14} \mathrm{CN}$-labelled cyanocobalamin was added to the partially purified binding protein from pig stomach and the whole was dialysed, no radioactivity could be detected in the dialysate. After purification (as described above), the pink protein complex still contained carbon-14. activity, indicating that the protein did not displace the cyanide during combination with the vitamin.

Specific groups on the molecule of the protein isolated from sow's milk were blocked by various reagents, and the capacity of the modified protein to bind cyanocobalamin was measured. Free - $\mathrm{SH}$ groups were not necessary for the binding. An $-\mathrm{NH}_{2}$ or $>\mathrm{NH}$ group may be involved since, after reacting with fluorodinitrobenzene, the protein no longer bound cyanocobalamin. However, milder treatments for blocking $-\mathrm{NH}_{2}$ groups, such as 3 per cent formaldehyde at $p \mathrm{H} 8$ or an acetylation procedure using acetylthioethylacetamide at $p \mathrm{H} 10^{\text {? }}$, did not interfere with the binding.

For a quantitative microbiological estimation of the cyanocobalamin in the complex, preliminary digestion with papain or trypsin is necessary. Enzyme digestion converts the microbiologically inactive cyanocobalamin complex into a form fully active for Lactobacillus leichmannii when heated with the assay medium but having only 20 per cent of this activity when assayed unheated. Furthermore, ultrafiltrations of the unheated and heated digests showed that not more than 10 per cent of the total cyanocobalamin had become ultra-filtrable. Since cyanocobalamin itself can be ultra-filtered quantitatively, it appears possible that the digest contains peptide conjugates of cyanocobalamin.

There seems no doubt that the substance isolated by us from sow's milk is very similar to the cyanocobalamin-protein isolated by Wijmenga et al. from hog gastric mucosa. The only discrepancy is that we find that $1 \mathrm{mgm}$. of the complex contains $23 \cdot 6 \mu \mathrm{gm}$. cyanocobalamin, whereas Wijmenga et al. find only $12 \cdot 3 \mu \mathrm{gm}$

We wish to thank Dr. E. Lester Smith (Glaxo Laboratories) for gifts of ${ }^{60} \mathrm{Co}$ cyanocobalamin and ${ }^{14} \mathrm{CN}$ cobalamin and the cyanocobalamin hydrolysis products, and Dr. S. K. Kon for his advice and interest in this work.

\section{Margaret E. Gregory}

E. S. HoldswortH

National Institute for Research in Dairying, University of Reading. Feb. 15.

1 Gregory, M. E., and Holdsworth, E. S., Biochem. J., 55, 830 (1953). ${ }^{2}$ Holdsworth, E. S., Biochem. J., 55, xiv (1953).

${ }^{3}$ Wijmenga, H. G., Thompson, K. W., Stern, K. G., and O'Connell, D. J., Biochim. et Biophys. Acta, 13, 144 (1954).

4 Holiday, E. R., Biochem. J., 30, 1795 (1936).

Gregory, M. E., Ford, J. E., and Kon, S. K., Biochem. J., 51, xxix (1952).

- Armitage, J. B., Cannon J. R. Johnson, A. W., Parker, L. F. J. Smith, E. L., Stafford, W. H., and Todd, A.'R., J. Chem. Soc., 3849 (1953). ' Baddiley, J., Kekwick, R. A., and Thain, E. M., Nalure, 170, 968
(1952). 